(C) 2015

Канівець Н. С., магістр ветеринарної медицини

Полтавська державна аграрна академія

\title{
ЛІКУВАННЯ ТЕЛЯТ ЗА ВИРАЗКИ ЯЗИКА
}

\section{Рецензент - кандидат ветеринарних наук С. Б. Передера}

На основі комплексного дослідження обтрунтовано лікування телят за виразки язика. В результаті досліджень біологічних субстратів у хворих тварин встановлено підвищення: в слині - вмісту альбумінів у 1,8 рази, в сироватці крові - активності АсАТ у 1,7 рази, ГГТП $і$ ЛФ у 1,5 і 2 рази відповідно. Ці зміни свідчать, щуо виразка язика у великої рогатої худоби часто супроводжується розвитком гепатодистрофії. Застосування комплексної терапії (20\% розчин натрію тераборат у гліцерині та Гепавекс 200) за иієї патологї̈ у телят супроводжується позитивними змінами біохімічних показників крові, які вказують на відновлення обмінних процесів печінки.

Ключові слова: телята, виразка, язик, печінка, активність ферментів, тварини.

Постановка проблеми. Виразка язика (лат. ulcus linguae) - це порушення цілісності слизової оболонки і прилеглих до неї тканин у результаті їх некрозу з наступним відторгненням, що повільно загоюється внаслідок лізису клітинних елементів та розвитку патологічних грануляцій [2]. Встановлено, що розвиток виразки язика у великої рогатої худоби супроводжується розладами травлення - гіпорексією, гіперсалівацією, гіпотонією передшлунків [3]. За таких умов печінка, як центральний орган метаболізму, зазнає значного функціонального навантаження. Зважаючи на вищевказане, видається доцільним пошук патогенетичних зв'язків між окремими порушеннями стану ротової порожнини та печінки, шляхом аналізу складу слини та біохімічних показників крові, які характеризують стан печінки у тварин із виразкою язика. Отримані результати можуть слугувати обгрунтуванням комплексної схеми лікування хворих тварин.

Аналіз останніх досліджень і публікацій, у яких започатковано розв'язання проблеми. Проблема виразки язика у великої рогатої худоби є предметом досліджень багатьох учених, починаючи з 1880 року [7]. Серед сучасних дослідників даним питанням займались J. Cristea [9], A. М. Катаранов [3], В. А. Світайло [6], T. Bazargani [8]. Отримані дані свідчать, що виразка язика є ознакою порушення метаболічних реакцій в організмі та супроводжується патологічними змінами різних органів і систем. Проте відомі публікації не містять даних щодо зв'язку змін стану ротової порожнини та функцій печінки за виразки язика у великої рогатої худоби. Відкритим залишається також питання комплексного лікування хворих тварин. Тому науковий пошук у цьому напрямі є актуальним.

У попередніх публікаціях нами висвітлені окремі показники складу слини та вмісту рубця за виразки язика, а також наведені зміни структури язика і печінки [5]. Однак для призначення обгрунтованого лікування необхідно провести дослідження окремих показників сироватки крові тварин.

Метою досліджень стало обгрунтування лікування телят за виразки язика із застосуванням засобів, що виявляють гепатопротекторну дію.

Для i досягнення головним завданням було проаналізувати результати біохімічного дослідження слини і сироватки крові хворих телят і визначити ефективність лікування.

Матеріали і методи досліджень. Дослідження проводили у два етапи в умовах МТФ ДП СП «Ювілейне» у осінньо-зимовий період 20102011 року на телятах 6-9-місячного віку. На першому етапі досліджували слину і сироватку крові хворих та клінічно здорових тварин $(\mathrm{n}=10)$.

Зразки слини відбирали у пробірки в кутку рота, відводячи нижню губу донизу. У зразках слини визначали вміст альбумінів, кальцію та неорганічного фосфору за допомогою автоматичного біохімічного аналізатора АБхФк-02-«НППТМ». Кров для дослідження відбирали з яремної вени вранці до годівлі. У сироватці крові визначали активність аспартатамінотрансферази (АсАТ) (за методом Райтмана-Френкеля); гамма-глутамілтранспептидази (ГГТП) - колориметрично; лужної фосфатази (ЛФ) - за реакцією гідролізу динатрійфосфату [1].

На другому етапі проводили лікування телят 3 виразкою язика. Для цього було сформовано дві дослідні групи по 10 голів у кожній. Тваринам першої групи призначили $20 \%$ розчин натрію тетраборату у гліцерині, місцево для змащування виразок язика двічі на добу впродовж двох тижнів та Гепавекс 200 - внутрішньо в дозі 20 мл на голову один раз на добу впродовж семи днів. 


\section{СТОРІНКА МОЛОДОГО ВЧЕНОГО}

Для тварин другої групи застосовували лише $20 \%$ розчин натрію тетраборату у гліцерині. У телят обох груп відбирали кров на початку та на 14-ту добу лікування. У сироватці визначали активність АсАТ, ГГТП, ЛФ. Отримані дані порівнювали із результатами клінічно здорових телят $(n=10)$.

Результати дослідження оброблені статистично за допомогою прикладного програмного забезпечення Microsoft Excel XP.

Результати досліджень. За результатами досліджень змішаної слини хворих телят було виявлено тенденцію до зменшення рівня кальцію в 1,5 рази та неорганічного фосфору на $16,1 \%$ (табл. 1). Проте вміст альбумінів перевищував у 1,8 рази показник клінічно здорових. Це підтверджує порушення гомеостазу ротової порожнини у тварин за виразки язика.

У сироватці крові хворих телят виявили підвищення активності AcAT (табл. 2), у 1,7 рази $(\mathrm{p}<0,001)$, порівняно 3 показником клінічно здорових. Зростання активності ферменту вказує як на цитоліз гепатоцитів, так і на руйнування клітин м'язової тканини в ділянці виразки язика, оскільки АсАТ міститься й у мембранах міоцитів.

У тварин за виразки язика реєстрували підвищення активності ГГТП у 1,5 рази, порівняно 3 показником клінічно здорових, а лужної фосфатази - відповідно вдвічі, що свідчить про пошкодження жовчних шляхів печінки.

Таким чином, за виразки язика у телят виявляється підвищення рівня альбумінів у слині та зростання активності АсАТ, ГГТП, лужної фосфатази в сироватці крові, що вказує не лише на патологію ротової порожнини, але й на дистро- фічні порушення печінки.

Отже, як свідчать отримані результати та результати попередніх наших публікацій [4], виразка язика у великої рогатої худоби часто супроводжується розвитком гепатодистрофії. Тому під час лікування хворих телят ми врахували можливий одночасний перебіг цих патологій.

За виникнення виразки язика у великої рогатої худоби відбуваються істотні зміни структурних елементів гепатоцитів, на що вказує підвищення активності АсAТ. Активність АсАТ у хворих телят обох груп перевищувала середні значення здорових у 1,5 рази (рис. 1). У тварин першої групи активність АсАТ до лікування становила $103,0 \pm 1,67$ Од/л. На 14 добу лікування вона зни-

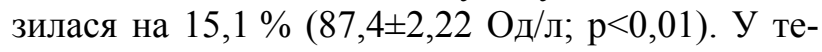
лят другої дослідної групи, навпаки, виявили тенденцію до підвищення активності АсAТ на $3 \%$. У цих тварин після лікування активність ферменту залишалася вірогідно вищою, ніж у клінічно здорових, на 45,3\%, а в першій групі на $25,2 \%(\mathrm{p}<0,001)$.

Активність ГГТП у телят першої групи до лікування була вище на $26,7 \%$ (p $<0,001$; рис. 2 ), у другій - не мала істотної різниці. Водночас у тварин обох груп спостерігали підвищення активності ЛФ у 1,9 разів, ніж у здорових ( $<0,001$; рис. 3 ).

По закінченню досліду в телят першої групи активність ГГТП помітно зменшилася до $16,6 \pm 1,26$ Од/л $(\mathrm{p}<0,05)$, другої - не змінилась $(20,4 \pm 1,03$ проти $20,4 \pm 0,50$ Од/л) і була вище на $21,2 \%$, у порівнянні 3 клінічно здоровими $(\mathrm{p}<0,05)$ та на $24,1 \%-3$ першою групою $(\mathrm{p}<0,05)$.

\section{1. Окремі показники слини телят за виразки язика $(n=10)$}

\begin{tabular}{|c|c|c|}
\hline \multirow{2}{*}{ Показник } & Клінічно здорові & Хворі \\
\cline { 2 - 3 } & $\mathrm{M} \pm \mathrm{m}$ & $\mathrm{M} \pm \mathrm{m}$ \\
\hline Кальцій, ммоль/л & $2,6 \pm 0,36$ & $1,7 \pm 0,30$ \\
\hline \multirow{2}{*}{ Неорганічний фосфор, ммоль/л } & $3,2 \pm 0,23$ & $2,6 \pm 0,43$ \\
\hline Альбуміни, г/л & $1,0 \pm 0,04$ & $1,9 \pm 0,11^{* * *}$ \\
\hline
\end{tabular}

Примітка: *** $\mathrm{p}<0,001$ - порівняно з показником клінічно здорових тварин

\section{2. Активність ферментів сироватки крові телят за виразки язика (n=10)}

\begin{tabular}{|c|c|c|}
\hline \multirow{2}{*}{ Показник } & Клінічно здорові & Хворі \\
\cline { 2 - 3 } & $\mathrm{M} \pm \mathrm{m}$ & $\mathrm{M} \pm \mathrm{m}$ \\
\hline АсАТ, Од/л & $67,3 \pm 2,51$ & $106,6 \pm 2,91^{* * *}$ \\
\hline ГГТП, Од/л & $14,3 \pm 0,73$ & $21,2 \pm 0,83^{* *}$ \\
\hline Лужна фосфатаза, Од/л & $104,3 \pm 10,14$ & $205,2 \pm 5,38^{* * *}$ \\
\hline
\end{tabular}

Примітка: $* * \mathrm{p}<0,01 ; * * * \mathrm{p}<0,001-$ порівняно з показником клінічно здорових тварин 


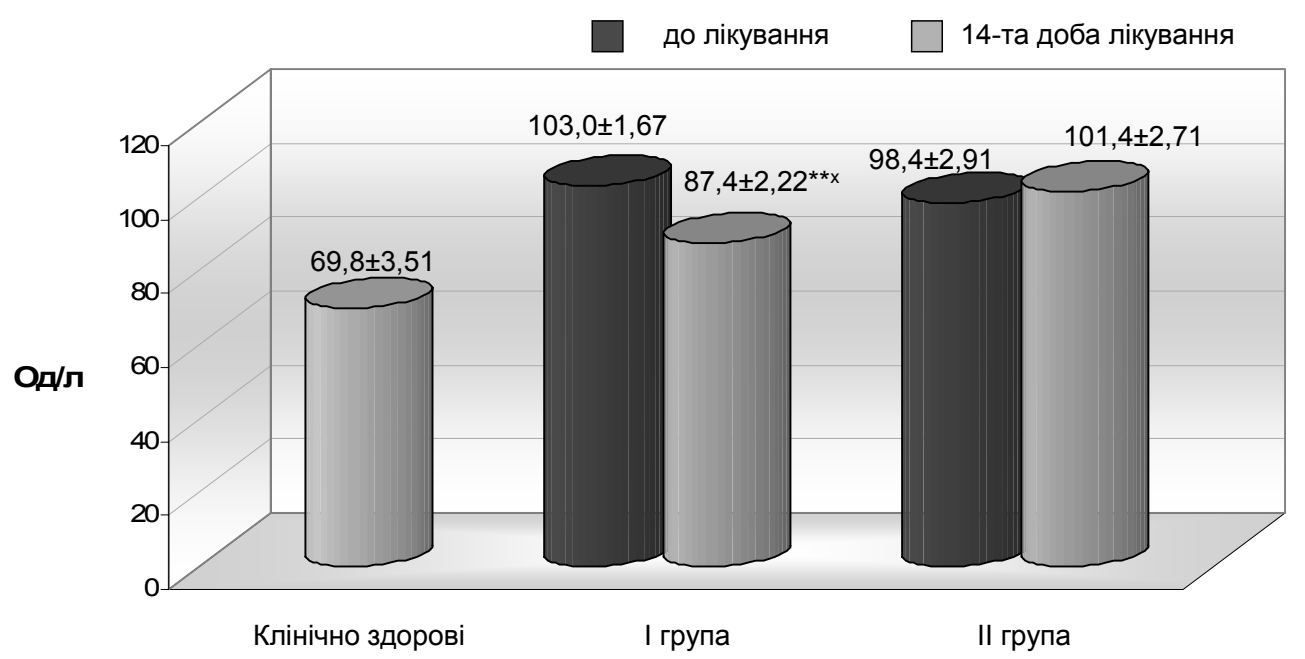

Рис. 1. Активність АсАТ у сироватці крові під час лікування телят з виразкою язика $\left({ }^{* *} p<0,01-\right.$ порівняно з показниками до лікування; $x p<0,05$ - порівняно з першою групою)

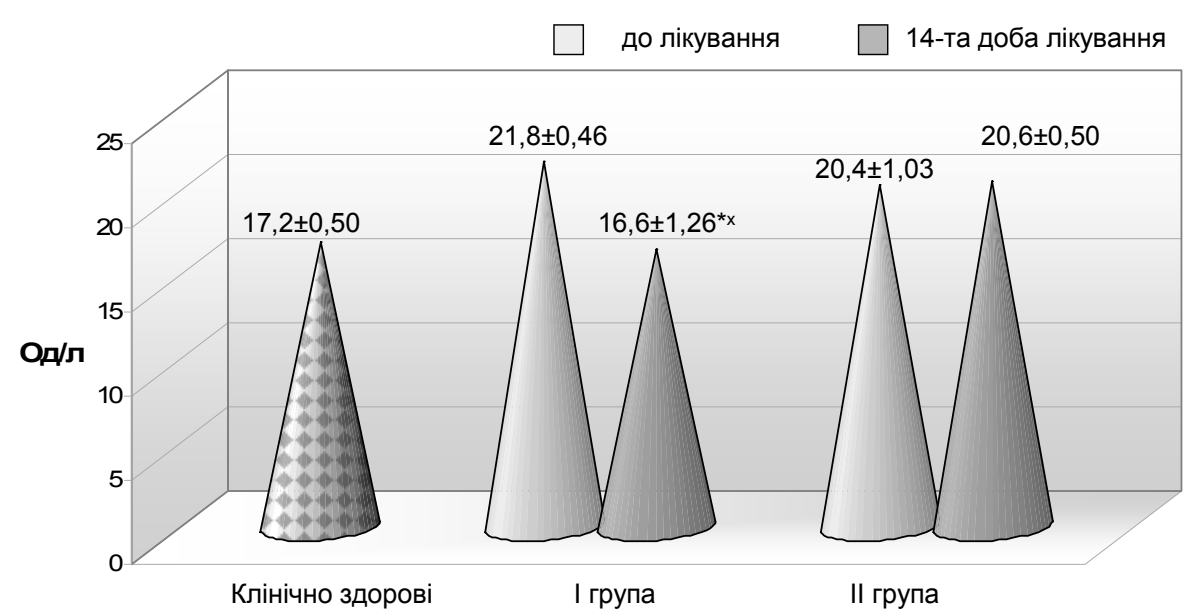

Рис. 2. Активність ГГТП сироватки крові телят під час лікування виразок язика ( ${ }^{*} p<0,05$ - порівняно з показниками до лікування; $x p<0,05$ - порівняно з першою групою)

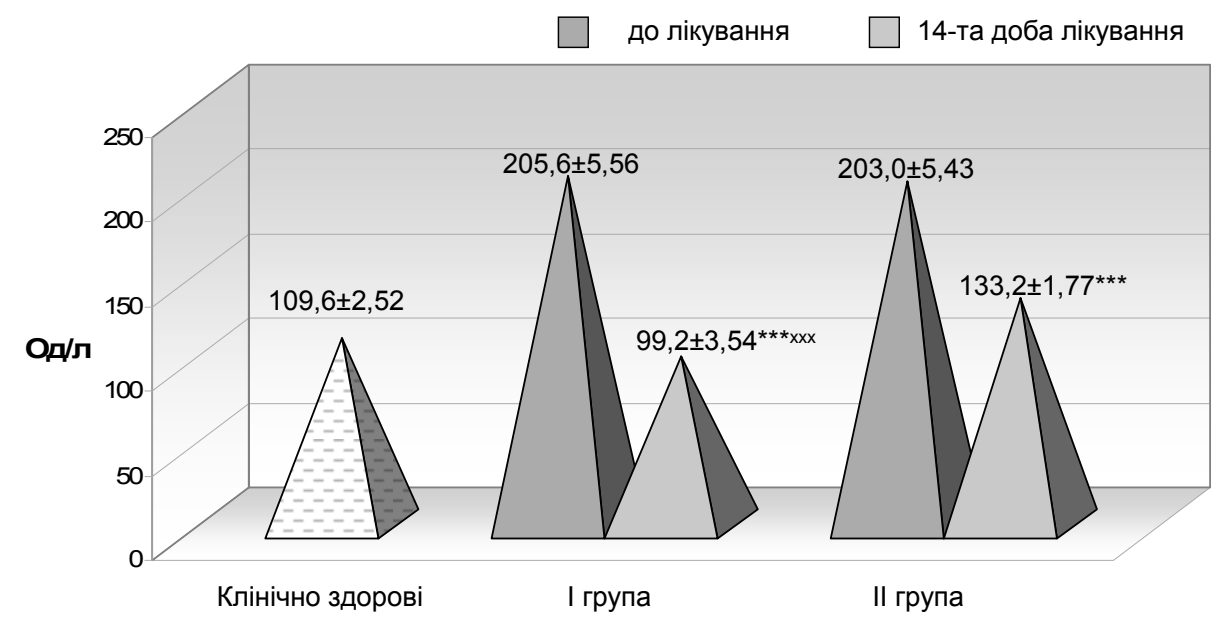

Рис. 3. Активність ЛФ сироватки крові під час лікування телят з виразкою язика (***p<0,001 - порівняно з показниками до лікування; хххр <0,001 - порівняно з першою групою) 


\section{СТОРІНКА МОЛОДОГО ВЧЕНОГО}

Активність лужної фосфатази на 14-ту добу лікування знизилась: у першій групі в 2,1 рази $(\mathrm{p}<0,001)$, другій - лише на $34,4 \%(p<0,001)$ порівняно з показником до лікування та у 1,3 рази була вища за показник першої групи $(\mathrm{p}<0,001)$.

Отже, використання першої схеми лікування сприяє відновленню цитозольної і мітохондріальної структур гепатоцитів. Це, очевидно, зумовлено дією гепатопротектора Гепавекс 200, складова частина якого DL-Метіонін - незамінна амінокислота, яка сприяє синтезу холіну та знешкоджує окремі токсичні речовини шляхом метилування, карнітину гіпохлорид нормалізує жировий і білковий обміни та володіс регенеративною дією. Водночас проведення лише місцевого лікування (друга схема) тимчасово гальмує запаль-

\section{БІБЛІОГРАФІЯ}

1. Біохімічні методи дослідження крові тварин : [метод. рекоменд. для лікарів хім.-токс. відділів держ. лаб. вет. мед. України, слухачів ф-тів підвищення кваліф. та студ. ф-тів вет. мед. / [Левченко В. І., Новожицька Ю. М., Сахнюк В. В. та ін.]. Київ, 2004. - 104 с.

2. Заболевание слизистой оболочки полости рта : учеб. пособ. / [Данилевский Н. Ф., В. К. Леонтьев, Несин А. Ф., Рахний Ж. И.]. - М. : ОАО «Стоматология», 2001. $-272 \mathrm{c}$.

3. Катаранов А. Н. Язвенная болезнь языка у крупного рогатого скота : автореф. дис. на соиск. уч. степени к. вет. н. : спец. 16.00.01 «Диагностика и терапия животных» / А. Н. Катаранов. - Саратов, 1984. -20 c.

4. Локес П. І. Патоморфологічні зміни печінки за виразок язика у великої рогатої худоби / П. І. Локес, М. В. Скрипка, Н. С. Канівець // Вісник Сумського національного аграрного університету : серія «Ветеринарна медицина». - 2013. Вип. 9 (33). - С. 156-158.

5. Локес П. І. Склад слини телят віком шести місяців за виразкових процесів язика / П. І. Локес, М. В. Скрипка, Н. С. Канівець // ний процес на язиці, однак не може відновити порушену функцію печінки, що, у свою чергу, характеризується хронічним перебігом виразок язика і перешкоджає їх повному загоєнню.

Висновок. Результати проведених досліджень свідчать, що за виразки язика відбуваються зміни стану ротової порожнини, а саме зростання у слині рівня альбумінів.

Крім цього розвиваються дистрофічні зміни печінки, на що вказує гіперферментемія (АсAT, ГГПТ, ЛФ).

Застосування комплексної схеми лікування телят за виразки язика, що включає гепатопротектор, супроводжується позитивними змінами біохімічних показників крові, які вказують на відновлення обмінних процесів в організмі.

Наукові праці Полтавської держ. аграр. акад. : серія «Ветеринарна медицина». - Полтава, 2013. Вип. 6. - С. 41-45.

6. Свитайло B. A. Иммунологический и биохимический статус у крупного рогатого скота при язвах языка : автореф. дис. на соиск. уч. степени к. вет. н. : спец. 16.00.03 «Ветеринарная микробиология, вирусология, микология с микотоксикологией и иммунологией» : спец. 16.00.05 «Ветеринарная хирургия» / В. А. Свитайло. Курск, 2006. - 16 с.

7. Частная патология и терапия домашних животных / [Гутира Ф., Марек И., Маннингер Р., Мочи И.]. - [11-е изд., перераб.]. - М. : Сельхозиздат, 1963. - Т. II. - Кн. 3. -572 с.

8. Bazargani T. Idiopathic lingual fossa ulcer in cattle in Iran / T. Bazargani, A. R. Movassaghi, J. Bakhtiari // Iranian Jor. of Vet. Research, Shiraz Univ. 2008. - Vol. 9. - №2. - Ser. № 23. - P. 168-170.

9. Cristea J. Observations on the traumatic tongue ulcer of cattle in the area of Baia-Mare, $\mathrm{Ru}-$ mania / J. Cristea, V. Căpătînă // Dtsch. Tierarztl. Wochenschr. - 1971. - 78 (17). - P. 473-475. 